\title{
Defining an Anarchist-Sociology: A Long Anticipated Marriage
}

\author{
Dana M. Williams ${ }^{\mathrm{i}}$ and Jeff Shantz ${ }^{\mathrm{ii}}$
}

There is no established intellectual tradition of an "anarchistsociology"-yet. A vibrant synthesis of anarchism and sociology has yet to be generated, whether that synthesis would be mere subject matter or a subfield within Sociology, or if it were an established ideology or theoretical tradition. Here, we compare these two distinct traditions, with an eye towards potential overlap. A definition for anarchist-sociology rooted in praxis - a critique of society and a transformative vision of societies-is created. As anarchism has a strong-yet unfocused - sociological theme already, we focus on anarchizing the discipline of Sociology in-line with core anarchist values, namely freedom, anti-authoritarianism, direct action, mutual aid, and decentralization. [Article copies available for a fee from The Transformative Studies Institute. E-mail address: journal@transformativestudies.org Website: http://www.transformativestudies.org @2011 by The Transformative Studies Institute. All rights reserved.]

KEYWORDS: Anarchism, Sociology, Synthesis, Theory, Activism, Discipline, Research.

\section{INTRODUCTION}

Anarchism is of increasing significance in the world of social movements (Graeber 2002). There are anarchist currents running through many of modern social movements, such as the global justice movement (Epstein 2001). But, this influence is not isolated to movements. The influence of the anarchist movement has also infiltrated the academy and has linked

\footnotetext{
${ }^{\mathrm{i}}$ Address correspondence to: Dana Williams, Department of Sociology, Anthropology, and Criminal Justice, University Center, Room 1137, Valdosta State University, Valdosta, GA 31698; e-mail: danawilliams@valdosta.edu.

ii Address correspondence to: Jeff Shantz, Department of Criminology, Kwantlen Polytechnic University, Surrey, B.C., Canada; e-mail: Jeffrey.Shantz@kwantlen.ca. Acknowledgments: Many thanks to Suzanne Slusser.
} 